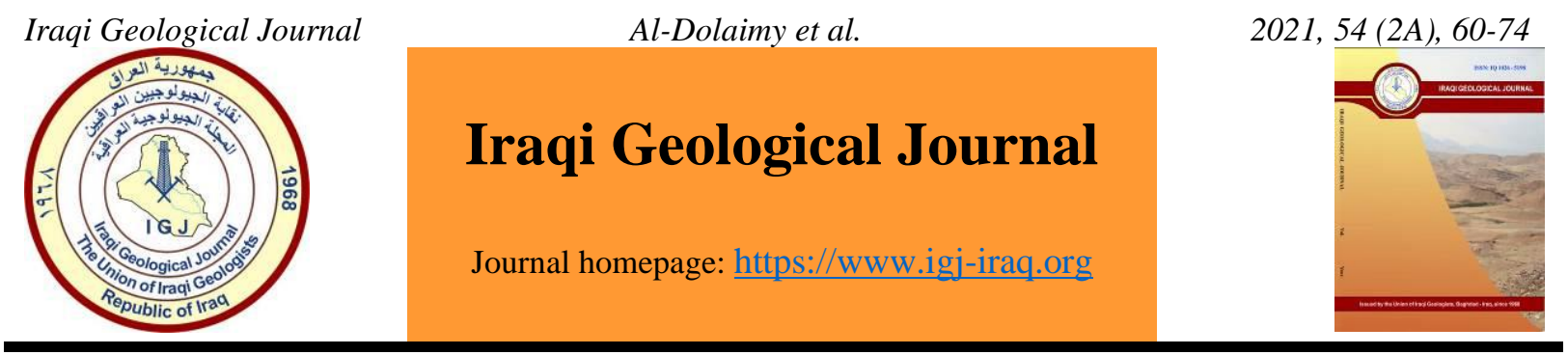

\title{
Source Rock Characteristic of Sargelu and Kurrachine Formations from the Selected Wells in Northern Iraq
}

\author{
Arwa M. S. Al-Dolaimy ${ }^{1, *}$, Aahed Y. Al-Mallah ${ }^{1}$, Mohamed I. Abdel-Fattah ${ }^{2}$ and \\ Fawzi M. Al-Beyati ${ }^{3}$ \\ ${ }^{1}$ Department of Geology, College of Science, Mosul University, Mosul, Iraq \\ ${ }^{2}$ Department of Geology, Faculty of Science, Suez Canal University, Ismailia, Egypt \\ ${ }^{3}$ Technical college of Kirkuk, Northern Technical University, Iraq \\ * Correspondence: mhmdar3@gmail.com
}

Received: 22 February 2021; Accepted: 21 April 2021; Published: 31 July 2021

\begin{abstract}
A total of 56 cuttings samples of Sargelu and Kurrachine formations from different wells (Ain Zalah, Baiji, and Jabal Kand) in northern Iraq have been investigated in this study. Both the Sargelu and Kurrachine formations were examined using Rock-Eval pyrolysis to assess the richness of organic matter and thermal maturity level. The Sargelu Formation have Total Organic Carbon wt.\% ranged from 0.22-2.52 wt.\%, average 1.26 wt.\% in Ain Zalah Well, and between 0.57-8.90 wt.\%, average 2.95 wt.\% in Baiji Well, and between 0.81-11.80 wt.\%, average $5.01 \mathrm{wt} . \%$ in for Kand Well. It is considered a potential source rock based on total organic carbon content. total organic carbon wt. \% in Ain Zalah and Kand in the Kurrachine Formation is considered poor source rock with a total organic carbon content of $0.17,0.39 \mathrm{wt} . \%$, respectively, while in Baiji Well is considered moderate source rock with total organic carbon content $0.53 \mathrm{wt}$. $\%$. The Rock-Eval data are not always sufficient to define the kind of organic matter through the use of the van Krevelen diagram because HI and OI are affected by both matrix mineralogy and the kerogen mixture. For accurate assessments of the source rocks, gas chromatography has been relied on, which provides a direct indication of the kerogen type as well as the type of hydrocarbons that kerogen can generate during maturity. Gas chromatography analysis indicates that all selected samples contained type II kerogen. The highest value of the TAS/ (MAS+TAS) ratio was found in Ain Zalah samples (Sargelu Formation), and this result indicates the occurrence of an aromatization process with increasing thermal maturation.
\end{abstract}

Keywords: Sargelu; Kurrachine; Source rock; Organic matter; Maturity; Aromatic

\section{Introduction}

Petroleum source layers are fine-grained, silicate rocks rich in clay (mudstone, shales) or dark-colored carbonate rocks (marlstones, limestone) that have generated and expelled hydrocarbon effectively (Leythaeuser, 2005). The source rocks contain great quantities of organic material consequent from the death of different species, including animals and plants, entombed and to different processes of heat and pressure for millions of years and is capable to produce significant amounts of hydrocarbons which can produce oil and gas. Peters et al. (2012) distinguished the petroleum source

DOI: 10.46717/igj.54.2A.5Ms-2021-07-26 
rock into effective, active, and inactive potential as follow; Effective: Currently it is generating or has been generated and expelled; Potential: Containing organic matter in sufficient quantities but not yet expelled; Active: Petroleum is generated subjected and expelled at the critical moment; Inactive: Stopped generating due to uplift and/or reduced thermal stress, despite petroleum potential remains.

Source rock is one of the essential elements for generating hydrocarbon, and the capacity of source rocks for petroleum generation is based on the (quantity, quality) of organic matter and thermal maturity (Peters and Cassa, 1994). Different studies were done on the Sargelu Formation (Middle Jurassic) and Kurrachine Formation (Upper Triassic) source rocks. They have been studied from outcrops and well cuttings by many researchers e.g. Jassim and Al-Gailani (2006) studied petroleum systems in the Triassic and Jurassic; Al-Ameri et al. (2009) in their study on the palynofacies of the upper units of Kurrachine and Baluti formations concluded that the organic matter within the Kurrachine Formation consists of thermally mature mixed kerogen types II and III; Abdula (2010 and 2015) identified two types of kerogen (II and III) in the Sargelu Formation and he showed through the pyrolysis analysis that complete organic carbon is decreasing towards the north and northeast areas of Iraq; Al-Badry investigated geochemistry and stratigraphy of Jurassic formations in northern Iraq in 2012 and concluded that Chia Gara, Naokelekan, and Sargelu formations are all good source rocks for generating and producing hydrocarbons. Furthermore, he stated that the Sargelu Formation characterized by type II with a low contribution by type I; Hussein et al. (2013) evaluated Jurassic source rocks geochemically northern Iraq and concluded that there are two types of kerogen in the Sargelu Formation, I and II, and described the source rocks as good to excellent with an average total organic carbon content is more than 4.69\%; Al-Ameri et al. (2013) reported that the generation and expulsion of petroleum in the Sargelu Formation started and ended in the Miocene; Aqrawi and Badics (2015) assessed potentiality and volumetric capability of shale oil/gas of the middle Jurassic-lower Cretaceous and they concluded that the Naokelekan, Sargelu and Najmah formations could be the best plays of shale-gas/shale-oil in Iraq, Iran, and Kuwait due to their organic richness; Fatah and Mohialdeen (2016) determined the mixture of types II/III kerogen from Sargelu Formation in Miran Oil Field in Sulaymaniyah Governorate and based on the production index (PI), the organic material in the Sargelu is thermally mature; Sargelu Formation samples in Zab-1 Well with production index values ranging from 0.15 to 0.25 (average 0.19 ) and $\mathrm{T}_{\max }$ values ranging from $422{ }^{\circ} \mathrm{C}$ and $431{ }^{\circ} \mathrm{C}$ (average $427{ }^{\circ} \mathrm{C}$ ), suggesting thermally immature to early mature source (Abdula, 2016); Awdal et al. (2016) concluded that the Kurrachine Formation in the Kurdistan Region is widely fractured and has a good network of fractures; therefore, the production of hydrocarbon comes mainly from secondary porosity within the fractured dolomitized rocks; The petroleum system of Jabal Kand Oil Field shows that the Sargelu Formation is immature and has not generated any oil Ro< $0.55 \%$ (Abdula, 2017); Hakimi et al. (2017) explained through the burial/thermal history model that the source rock of the Sargelu Formation has passed the oil generation window since the late Eocene to late Miocene. The results show that the Sargelu marine type IIS kerogen in Bijeel Oil Field is a potential source of hydrocarbon and is thermally mature with relation to the oil window. In the analyzed samples that they studied, carbonate is richer in organic matter and more oil-prone than silty mudstones and carbonaceous shales (Abdula et al., 2017); Edilbi et al. (2019) in their study on the potential of source rocks and basin modeling of the Kurrachine Formation concluded that the formation consists of mixed types III and II-III kerogen, and the values of $\mathrm{T}_{\max }$ show that the organic matter is mature. The aim of this research is to evaluate the potential of the source rocks by determining the type of kerogen using gas chromatography and to assess the rock maturity in the Sargelu and Kurrachine formations. 


\section{Study Area}

The study area is situated in northern Iraq and includes three oil wells, Kand (Kd-1), Ain Zalah (AZ-29), and Baiji (Bj-1) (Fig. 1).

\section{Geological Setting}

The Sargelu Formation is one of the most widespread formations in Iraq and neighboring countries. This formation appears in Iraq in several areas, (1) Balambo-Tanjero Zone; (2) Northern Thrust Zone; and (3) Qulqula- Khwakurk Zone. It is located all over Iraq, with the exception of the Rutba Subzone, where it is transformed into Muhaiwir Formation (Jassim and Buday, 2006). The type section is located in the High-Fold Zone in Surdash Area, northeastern Iraq. The type section is identified by Bellen et al. (1959) and they noted that the Sargelu Formation consists of thin-bedded calcareous black, bituminous calcareous, dolomitic calcareous, papery shale, and thin black chert strips. The proportion of clay admixture with sand is higher in subsurface sections (Jassim and Buday, 2006; Buday, 1980). The formation is rich in fossils both in outcrops and boreholes (Abdula et al., 2015). The thickness of the formation varies as it is $115 \mathrm{~m}$ in the type locality (Bellen et al., 1959). The contacts are conformable and gradational in the type section in Sargelu Village, but in north-west of Mosul, it overlaid by Cretaceous Sarmord Formation (Jassim and Buday, 2006).

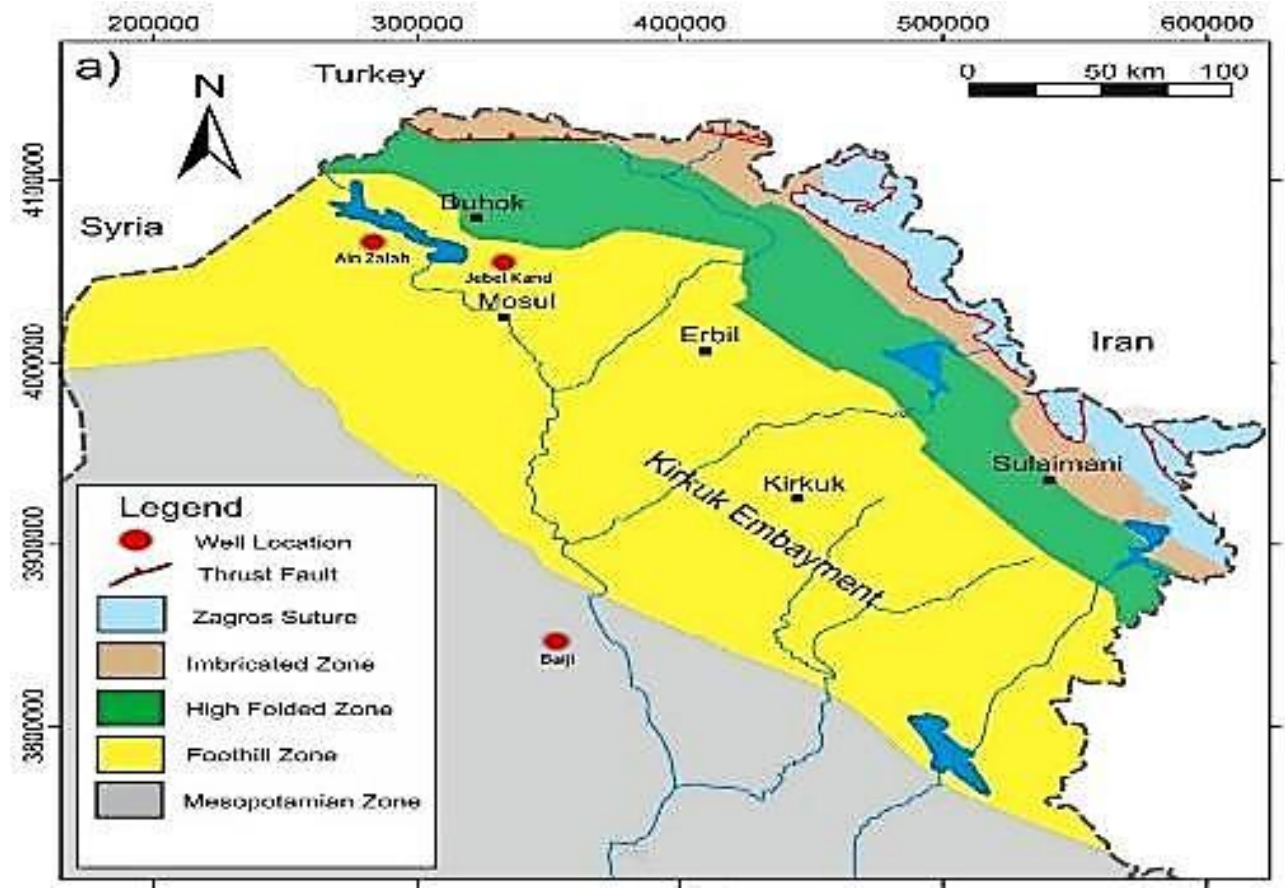

Fig.1. Location map of the studied wells

The Sargelu Formation was deposited in a reduced marine environment except for some parts of the formation that appear to have been deposited in shallow environments or better-aerated conditions in Salman Zone of the Stable Shelf, which represent the Muhaiwir Formation tongues (Jassim and Buday, 2006). The Sargelu Formation was deposited during Late Toarcian-Early Tithonian Megasequence AP7 (Jassim and Buday, 2006). The region of Iraq during the middle Jurassic Period is characterized by the occurrence of many calcareous and argillaceous facies, and according to Jassim and Buday (2006) all facies of this period were located in different regions of Iraq. The Kurrachine Formation is the most widely distributed formation within the Late Triassic sequence. This formation occurs in the central and northern parts of Iraq. The formation in the type section is comprised of dark brown and black limestone, thick and thin-bedded, with occasional layers of thick-bedded, fetid dolomites, with slump 
structures, and some papery shale (Bellen et al., 1959). Additionally, they determined the age of the formation to be Late Triassic (Rhaetic at the top).

The thickness of the formation in the type area is up to $850 \mathrm{~m}$ (Buday, 1980). The lower contact of the formation is characterized by an erosional break determined by haematitization and leaching of the underlying Geli Khana Formation. According to Bellen et al. (1959), the contact with overlying Baluti Formation is gradational and conformable. The environmental conditions of Kurrachine Formation are characterized by lagoonal, occasionally euxinic in the Mesopotamian and Foothill zones (Buday, 1980). Upper Triassic in north Iraq is part of an Upper Triassic-Middle Jurassic Cycle, which began with a regional transgression marking the beginning of the spreading sedimentary basins in the region (Buday, 1980).

\section{Material and Methods}

A total of 56 cuttings samples of shale from Sargelu and Kurrachine formations in different wells have been taken from the North Oil Company in Kirkuk, Iraq. The samples have been tested in the stratochem laboratory, Cairo, Egypt. Various methods have been applied to achieve the request of organic geochemical analyses such as total organic carbon by LECO analyzer, Rock-Eval pyrolysis, gas chromatography, and gas chromatography-mass spectrometry.

\subsection{Total Organic Carbon Analysis (TOC)}

The richness of organic matter is defined by the steps begins with weighing the samples in an Erlenmeyer flask and reacting with $\mathrm{HCl}$ to remove the carbonates. With a Millipore filter device, the sample is filtered into a microfiber filter paper and then washed by distilled water to slough traces of hydrochloric acid and placed in an oven for drying. The filter paper is transferred in a LECO crucible with the sample, which is then incinerated in the combustion oven. The amount of $\mathrm{CO}_{2}$ resulting from the combustion of organic matter is also detected with an infrared detector. This quantification is expressed as a weight percentage of TOC.

\section{2 The Rock-Eval Method}

Pyrolysis can be used to estimate the petroleum potential of source rock samples by using a heating program. The emitted hydrocarbons are observed by a flame ionization detector (FID), to generate two parameters (S1, S2). The temperature at which the highest amount of S2 formed is called Tmax, which gives an indication of the maturity of kerogen. In addition, the infrared IR can monitor the $\mathrm{CO}_{2}$ emitted during pyrolysis in real time, providing information on the kerogen oxidation state.

\section{3 Bitumen Extraction}

Extraction is the process of separating the adsorbed compounds from the rock matrix by repeatedly rinsing the sample (continuous extraction) with a suitable solvent. Soxhlet bitumen extraction was performed from sedimentary rocks with dichloromethane (DCM) for $72 \mathrm{~h}$. DCM is a very effective polar solvent for extracting and dissolving oils.

\section{4 Gas Chromatography (GC)}

Diluted samples were injected into chromatographic column and programmed from $60^{\circ} \mathrm{C}-350^{\circ} \mathrm{C}$ at a rate of $12^{\circ} \mathrm{C} / \mathrm{min}$ with an Agilent $7890 \mathrm{~A} \mathrm{GC}$ and Helium was used as carrier gas. Following the determination of the $<\mathrm{C} 15$ fraction by evaporation in a stream of $\mathrm{N}$ for 30 minutes and precipitation of asphaltene with excess n-hexane, the $\mathrm{C} 15+$ deasphalted are isolated into saturated, aromatic, and NSO fractions by gravity-flow column using a silica gel activated at $400^{\circ} \mathrm{C}$ before employing. Hexane was 
used to remove the saturated, dichloromethane to remove the aromatic and the NSO fractions, dichloromethane/methanol (50:50) was used. After the solvent has evaporated, the recovered fractions are measured by gravity method to concentrate the branched/cyclic biomarker fraction. The C15+ saturate fraction undergoes molecular sieve filtration based on West et al., (1990) technology.

\section{5 Gas Chromatography-Mass Spectrometry (GCMS)}

GC/MS technical of C15+ branch/cyclic and aromatic hydrocarbons was used with Agilent 7890A GC connected to a 5975C MS. During the analysis, helium is held at a steady flux rate. The J \& W DB5 column is a temperature scheduled to range from 150 to $325^{\circ} \mathrm{C}$ at $2 \mathrm{C} / \mathrm{min}$ (branched/cyclic) and from 100 to $325^{\circ} \mathrm{C}$ at $3{ }^{\mathrm{C}} \mathrm{C} / \mathrm{min}$ (aromatic). The spectrometer is set to selected ion mode (SIM), which monitors ions with $\mathrm{m} / \mathrm{z} \mathrm{177,} \mathrm{191,} \mathrm{205,} \mathrm{217,} \mathrm{218,} \mathrm{221,} \mathrm{231,} \mathrm{and} 259 \mathrm{amu}$ (branched/cyclic) and 156, 170, 178, 184, 192, 198, 231, 239 or 245 and 253 (aromatics). To assess absolute biomarker concentrations, a deuterated internal standard was applied to the $\mathrm{C} 15+$ branched/cyclic fraction. The aromatic hydrocarbon fraction was supplemented with a deuterated anthracene standard.

\section{Results and Discussion}

Rock-Eval pyrolysis is a rapid analysis that provides important information about the source rock's maturity; petroleum production capacity and the type of hydrocarbon produced (Peters, 1986). It is estimated the total amount of petroleum formed during the thermal decomposition of kerogen by Rock-Eval pyrolysis. The parameters obtained by Rock-Eval pyrolysis include S1 (free hydrocarbon exits in the rock sample before analysis), $S_{2}$ (Hydrocarbon compound generated by the cracking of Kerogen during pyrolysis, $S_{3}$ (Carbon dioxide released during the thermal cracking of kerogen), and Tmax (Maximum temperature at highest amount of $S_{2}$ generation). From these measured values, a number of additional parameters like oxygen index (OI=S3/TOC*100), hydrogen index $\left(\mathrm{HI}=\mathrm{S} 2 / \mathrm{TOC}^{*} 100\right)$ and production index $(\mathrm{PI}=\mathrm{S} 1 /(\mathrm{S} 1+\mathrm{S} 2)$ are determined and shown in Table 1. Interpretations of biomarker data and their derivatives such as the pristane/phytane ratio, and isoprenoid/n-alkanes ratio have been performed (Table2). While aromatic biomarker and $\mathrm{Ts} /(\mathrm{Ts}+\mathrm{Tm})$ trisnorhopanes are shown in Table 3.

Table 1. Analysis of TOC and Rock-Eval for cuttings samples selected from Sargelu and Kurrachine formations at different wells in northern Iraq

\begin{tabular}{|c|c|c|c|c|c|c|c|c|c|c|c|}
\hline Samples & Formation & $\begin{array}{c}\text { Depth } \\
\text { M }\end{array}$ & $\begin{array}{r}\text { TOC } \\
\text { Wt. \% } \\
\end{array}$ & $\begin{array}{c}\text { S1 } \\
\mathrm{mg} / \mathrm{g}\end{array}$ & $\begin{array}{c}\mathrm{S} 2 \\
\mathrm{mg} / \mathrm{g}\end{array}$ & $\begin{array}{c}\text { S3 } \\
\mathrm{mg} / \mathrm{g}\end{array}$ & $\begin{array}{c}\text { Tmax } \\
\mathrm{C}^{\circ}\end{array}$ & $\begin{array}{c}\text { HI } \\
\mathrm{mg} \mathrm{HC} / \mathrm{g} \text { TOC }\end{array}$ & $\begin{array}{c}\text { OI } \\
\mathrm{mg} \mathrm{CO} 2 / \mathrm{g} \text { TOC }\end{array}$ & PI & $\begin{array}{c}\text { S1/ } \\
\text { TOC }\end{array}$ \\
\hline AZS 1 & SARGELU & 2556 & 0.29 & & & & & & & & \\
\hline AZS 2 & SARGELU & 2585 & 0.22 & & & & & & & & \\
\hline AZS 3 & SARGELU & 2625 & 0.58 & 0.19 & 0.99 & 0.41 & 434 & 170 & 71 & 0.16 & 0.33 \\
\hline AZS 4 & SARGELU & 2644 & 1.38 & 0.26 & 2.13 & 0.54 & 441 & 154 & 39 & 0.11 & 0.19 \\
\hline AZS 5 & SARGELU & 2664 & 1.30 & 0.19 & 1.55 & 0.51 & 442 & 119 & 39 & 0.11 & 0.15 \\
\hline AZS 6 & SARGELU & 2689 & 0.75 & 0.18 & 0.86 & 0.49 & 441 & 115 & 66 & 0.17 & 0.24 \\
\hline AZS 7 & SARGELU & 2714 & 1.73 & 0.23 & 1.87 & 0.77 & 441 & 108 & 45 & 0.11 & 0.13 \\
\hline AZS 8 & SARGELU & 2730 & 2.52 & 0.55 & 3.37 & 0.52 & 444 & 134 & 21 & 0.14 & 0.22 \\
\hline AZS 9 & SARGELU & 2750 & 1.23 & 0.24 & 1.35 & 0.51 & 443 & 110 & 41 & 0.15 & 0.20 \\
\hline AZS 10 & SARGELU & 2779 & 1.64 & 0.41 & 2.12 & 0.54 & 442 & 129 & 33 & 0.16 & 0.25 \\
\hline AZS 11 & SARGELU & 2799 & 2.17 & 0.29 & 1.64 & 0.88 & 446 & 76 & 41 & 0.15 & 0.13 \\
\hline AZK 1 & KURRA CHINE & 3526 & 0.12 & & & & & & & & \\
\hline AZK 2 & KURRA CHINE & 3608 & 0.11 & & & & & & & & \\
\hline AZK 3 & KURRA CHINE & 3631 & 0.10 & & & & & & & & \\
\hline AZK 4 & KURRA CHINE & 3736 & 0.16 & & & & & & & & \\
\hline AZK 5 & KURRA CHINE & 3785 & 0.09 & & & & & & & & \\
\hline AZK 6 & KURRA CHINE & 3821 & 0.13 & & & & & & & & \\
\hline AZK 7 & KURRA CHINE & 3852 & 0.19 & & & & & & & & \\
\hline AZK 8 & KURRA CHINE & 3901 & 0.16 & & & & & & & & \\
\hline AZK 9 & KURRA CHINE & 3926 & 0.30 & & & & & & & & \\
\hline
\end{tabular}




\begin{tabular}{|c|c|c|c|c|c|c|c|c|c|c|c|}
\hline AZK 10 & KURRA CHINE & 4002 & 0.29 & & & & & & & & \\
\hline BJS 1 & SARGELU & 2414 & 5.53 & 1.02 & 29.61 & 1.29 & 433 & 535 & 23 & 0.03 & 0.18 \\
\hline BJS 2 & SARGELU & 2422 & 8.90 & 1.65 & 44.23 & 1.38 & 434 & 497 & 16 & 0.04 & 0.19 \\
\hline BJS 3 & SARGELU & 2426 & 3.54 & 0.55 & 9.63 & 1.90 & 429 & 272 & 54 & 0.05 & 0.16 \\
\hline BJS 4 & SARGELU & 2449 & 0.68 & 0.26 & 2.77 & 0.55 & 429 & 408 & 81 & 0.09 & 0.38 \\
\hline BJS 5 & SARGELU & 2465 & 0.77 & 0.31 & 2.76 & 0.63 & 423 & 359 & 82 & 0.10 & 0.40 \\
\hline BJS 6 & SARGELU & 2483 & 0.65 & 0.28 & 2.72 & 0.53 & 424 & 420 & 82 & 0.09 & 0.43 \\
\hline BJS 7 & SARGELU & 2492 & 0.57 & 0.15 & 2.12 & 0.83 & 421 & 374 & 146 & 0.07 & 0.26 \\
\hline BJK 1 & KURRA CHINE & 3378 & 0.60 & 0.13 & 1.31 & 0.85 & 433 & 217 & 141 & 0.09 & 0.22 \\
\hline BJK 2 & KURRA CHINE & 3390 & 0.50 & 0.06 & 0.70 & 0.96 & 429 & 140 & 192 & 0.08 & 0.12 \\
\hline BJK 3 & KURRA CHINE & 3413 & 0.22 & & & & & & & & \\
\hline BJK 4 & KURRA CHINE & 3550 & 0.38 & & & & & & & & \\
\hline BJK 5 & KURRA CHINE & 3583 & 0.97 & 0.42 & 2.44 & 1.14 & 425 & 251 & 117 & 0.15 & 0.43 \\
\hline BJK 6 & KURRA CHINE & 3636 & 0.54 & 0.17 & 1.59 & 0.84 & 436 & 293 & 155 & 0.10 & 0.31 \\
\hline BJK 7 & KURRA CHINE & 3644 & 0.47 & & & & & & & & \\
\hline JKS 1 & SARGELU & 2115 & 3.83 & 2.88 & 22.52 & 0.79 & 428 & 588 & 21 & 0.11 & 0.75 \\
\hline JKS 2 & SARGELU & 2130 & 11.30 & 1.14 & 43.94 & 3.26 & 434 & 389 & 29 & 0.03 & 0.10 \\
\hline JKS 3 & SARGELU & 2145 & 11.80 & 5.78 & 56.01 & 1.32 & 435 & 475 & 11 & 0.09 & 0.49 \\
\hline JKS 4 & SARGELU & 2163 & 2.71 & 0.99 & 14.54 & 0.99 & 429 & 537 & 37 & 0.06 & 0.37 \\
\hline JKS 5 & SARGELU & 2188 & 0.81 & 0.32 & 3.76 & 0.51 & 425 & 462 & 63 & 0.08 & 0.40 \\
\hline JKS 6 & SARGELU & 2202 & 1.25 & 0.47 & 5.15 & 0.86 & 427 & 412 & 69 & 0.08 & 0.38 \\
\hline JKS 7 & SARGELU & 2230 & 3.38 & 1.02 & 14.25 & 0.90 & 435 & 422 & 27 & 0.07 & 0.30 \\
\hline JKS 8 & SARGELU & 2248 & 4.73 & 2.08 & 25.36 & 0.88 & 432 & 536 & 19 & 0.08 & 0.44 \\
\hline JKS 9 & SARGELU & 2267 & 2.05 & 3.54 & 12.15 & 0.66 & 422 & 593 & 32 & 0.23 & 1.73 \\
\hline JKS 10 & SARGELU & 2271 & 8.23 & 1.16 & 39.52 & 0.76 & 436 & 480 & 9 & 0.03 & 0.14 \\
\hline JKK 1 & KURRA CHINE & 2963 & 0.30 & & & & & & & & \\
\hline JKK 2 & KURRA CHINE & 3000 & 0.42 & & & & & & & & \\
\hline JKK 3 & KURRA CHINE & 3135 & 0.28 & & & & & & & & \\
\hline JKK 4 & KURRA CHINE & 3206 & 0.50 & 0.34 & 1.38 & 0.65 & 418 & 274 & 129 & 0.20 & 0.68 \\
\hline JKK 5 & KURRA CHINE & 3396 & 0.54 & 0.13 & 0.92 & 0.53 & 422 & 171 & 99 & 0.12 & 0.24 \\
\hline JKK 6 & KURRA CHINE & 3455 & 0.66 & 0.22 & 1.29 & 0.55 & 421 & 196 & 84 & 0.15 & 0.33 \\
\hline JKK 7 & KURRA CHINE & 3605 & 0.65 & 0.15 & 1.08 & 0.53 & 433 & 165 & 81 & 0.12 & 0.23 \\
\hline JKK 8 & KURRA CHINE & 3750 & 0.21 & & & & & & & & \\
\hline JKK 9 & KURRA CHINE & 3840 & 0.18 & & & & & & & & \\
\hline JKK 10 & KURRA CHINE & 3958 & 0.32 & & & & & & & & \\
\hline JKK 11 & KURRA CHINE & 4060 & 0.27 & & & & & & & & \\
\hline
\end{tabular}

Table 2. Ratios of Pristane/Phytane, Pristane $/ \mathrm{nC}_{17}$, and Phytane $/ \mathrm{nC}_{18}$ for the analyzed samples

\begin{tabular}{cccccc}
\hline Formation & Sample & Depth $(\mathbf{m})$ & Pr/Ph & Pr/nC17 & Ph/nC18 \\
\hline \multirow{5}{*}{ Sargelu } & AZS3 & 2625 & 0.77 & 0.29 & 0.32 \\
& AZS8 & 2730 & 1.09 & 0.18 & 0.21 \\
& BJS2 & 2422 & 0.62 & 0.21 & 0.27 \\
& JKS3 & 2145 & 0.35 & 0.19 & 0.34 \\
& BJK1 & 3378 & 0.65 & 0.25 & 0.30 \\
Kurrachine & BJK5 & 3583 & 0.33 & 0.62 & 1.70 \\
& JKK4 & 3206 & 0.52 & 0.37 & 0.46 \\
& JKK7 & 3605 & 0.59 & 0.28 & 0.45 \\
\hline
\end{tabular}

Table 3. Aromatic biomarkers for selected samples

\begin{tabular}{|c|c|c|c|c|c|c|c|c|}
\hline Formation & $\begin{array}{c}\text { Sample } \\
\text { Name }\end{array}$ & $\begin{array}{c}\text { Depth } \\
\text { (m) }\end{array}$ & $\begin{array}{l}\mathrm{C}_{27} \% \\
\text { MAS } \\
\end{array}$ & $\begin{array}{l}\mathrm{C}_{28} \% \\
\text { MAS } \\
\end{array}$ & $\begin{array}{l}\mathrm{C}_{29} \% \\
\text { MAS } \\
\end{array}$ & $\begin{array}{c}\text { TAS/ } \\
\text { (MAS+TAS) } \\
\end{array}$ & $\begin{array}{c}\left(\mathbf{C}_{20}+\mathbf{C}_{21}\right) / \\
\sum \text { TAS }\end{array}$ & $\begin{array}{c}\mathrm{Ts} /(\mathbf{T s}+\mathbf{T m}) \\
\text { trisnorhopanes }\end{array}$ \\
\hline \multirow{6}{*}{ Sargelu } & AZS3 & 2625 & - & - & - & 1.0 & 0.55 & 0.74 \\
\hline & AZS8 & 2730 & - & - & - & 1.0 & 0.30 & 0.80 \\
\hline & BJS2 & 2422 & 37.7 & 31.9 & 30.4 & 0.33 & 0.46 & 0.10 \\
\hline & JKS3 & 2145 & 36.0 & 25.6 & 38.4 & 0.15 & 0.40 & 0.21 \\
\hline & BJK1 & 3378 & 32.8 & 29.8 & 37.4 & 0.55 & 0.22 & 0.19 \\
\hline & BJK5 & 3583 & 13.0 & 15.7 & 71.2 & 0.96 & 0.08 & 0.26 \\
\hline \multirow{2}{*}{ Kurrachaine } & JKK4 & 3206 & 32.0 & 23.1 & 44.9 & 0.93 & 0.08 & 0.31 \\
\hline & JKK7 & 3605 & 32.5 & 26.8 & 40.6 & 0.81 & 0.52 & 0.63 \\
\hline
\end{tabular}




\section{1 Organic Matter Richness}

The amount of organic matter in the source rock is measured by the content of the TOC . Determination of TOC can be considered as a first step to provide primary geochemical information for the evaluation of source rocks for Sargelu and Kurrachine formations (Table 1). According to Peters and Cassa (1994), the TOC wt. \% content of more than $1 \mathrm{wt}$ \% is considered a good source rock. The Sargelu Formation in Ain Zalah Well can be rated as having a good hydrocarbon potential (0.22\%-2.52\% averaging $1.26 \%)$, and Baiji Well as very good potential $(0.57 \%-8.90 \%$ averaging $2.95 \%)$ whereas Jabal Kand Well can be considered an excellent hydrocarbon potential $(0.81 \%$ to $11.80 \%$, averaging $5.01 \%$ ). The TOC content of the Kurrachine Formation in Baiji Well range from $0.22 \%-0.97 \%$ averaging $0.53 \%$ and can be considered as fair source rock, while Ain Zalah and Kand wells can be rated as having poor hydrocarbon potential (average of $0.17 \%$ and $0.39 \%$ ) for Ain Zalah and Kand, respectively (Table 1). This variation in TOC\% values between the wells as well as the variation within one well depends on several factors including sedimentation rate, proximity and distance from the beach, and sedimentary environment (Tyson, 1995).

\section{2 Quality of Organic Matter}

The ability to produce petroleum and the type of hydrocarbons generated depend on the quality of organic matter because various types of organic matter have various hydrocarbon generation prone (Tissot and Welte, 1984; Tyson, 1995). Kerogen is an insoluble sedimentary organic material capable of generating petroleum (Vandenbroucke, 2003). In petroleum studies, kerogen is classified into three main types I, II, and III based on the ratio between contents $\mathrm{C}, \mathrm{H}$, and $\mathrm{O}$. The organic facies with thermal maturity define the timing and the type (oil or gas) of the hydrocarbon that is produced and expelled from the source rock (Peters et al., 2005a). For example, source rocks containing organic matter type III kerogen from higher plants produce gaseous compounds as the main hydrocarbon phase, while those containing type I and II kerogen from bacteria and algae mainly produce oil. The potential of the source rock is reflected by the hydrogen index, and this is the distinguishing tool for identifying kerogen. Type I (HI >600 mg HC/g TOC) and type II (300-600 mg HC/g TOC) have great hydrocarbon generation capabilities, while the type III kerogen which has low HI, the ability to generate petroleum is limited. Thus, understanding the diversity of organic facies helps to explain why some sediments are both oil-and-gas prone, some are barren, and others produce only dry gas (Rogers, 1979). The hydrogen index can be plotted versus the oxygen index on a modified Van Krevelen scheme (Tissot and Welte, 1984). It is noticed from Fig. 2A, the organic matter in the Sargelu Formation is represented by Type II in the wells Baiji and Kand, and Type III in the Ain Zalah Well. As for the Kurrachine Formation, the type of kerogen is II/III in the wells Kand, and Baiji (Fig.2B). Tmax versus HI is commonly used to determine the type of Kerogen (Hunt, 1996). Determination of kerogen type using Tmax versus HI appears to be more accurate than HI versus OI. Some discrepancies between the results would be expected due to the carbonates affecting OI. In Sargelu Formation the majority of the samples of Kand fall under the type II kerogen and samples of Baiji fall under types II, as well as a mixture of types II-III, while all samples of Ain Zalah represented by the type III kerogen (Fig. 3A). The Kurrachine Formation's organic matter in wells Kand and Baiji belong to the type III kerogen and a mixture of types II-III (Fig. 3B).

It is essential to keep track of what happens when the source rocks mature. As the source rock generated and expels hydrocarbon the TOC content of source rocks can be reduced (Daly and Edman, 1987). This means that the TOC will decrease as the amount of reactive kerogen is consumed (Dembicki, 2009). The amount of hydrogen will also decrease which leads to a decrease in S2. The lowest average value of the $S_{2}(1.76 \mathrm{mg} \mathrm{HC/g}$ rock) was found in the samples of the Ain Zalah Well (Sargelu Formation) compared to the samples of Jabal Kand and Baiji Wells, where the average value of 
the $\mathrm{S}_{2}$ reached $23.72 \mathrm{mg} \mathrm{HC} / \mathrm{g}$ rock and $13.41 \mathrm{mg} \mathrm{HC/g}$ rock in both wells, respectively. The decrease in the $S_{2}$ value of the samples of the Ain Zala well may be due to maturity of its source rocks.

However, Rock-Eval data by itself are not always sufficient to determine the type of organic matter when mixtures of kerogen are present (Dembicki, 1993). The TOC content of rocks can decrease significantly during thermal maturation. Losses are great in type I and II kerogens as approximately $70 \%$ and 50\%, respectively of the organic carbon content are liberated during generation and expulsion of hydrocarbon. In comparison, the carbon loss in type III kerogen is not significant with decrease estimates ranging from 12-20\% (Daly and Edmanm, 1987). In addition, the mineral matrix in the source rock can affect the Rock-Eval parameters. In sediments with a TOC content $(<2.0 \%)$, the retention of hydrocarbons on mineral grain can lead to a significant reduction in hydrogen index (Katz, 1983), while present carbonate minerals can increase the oxygen index (Dembick, 1993).
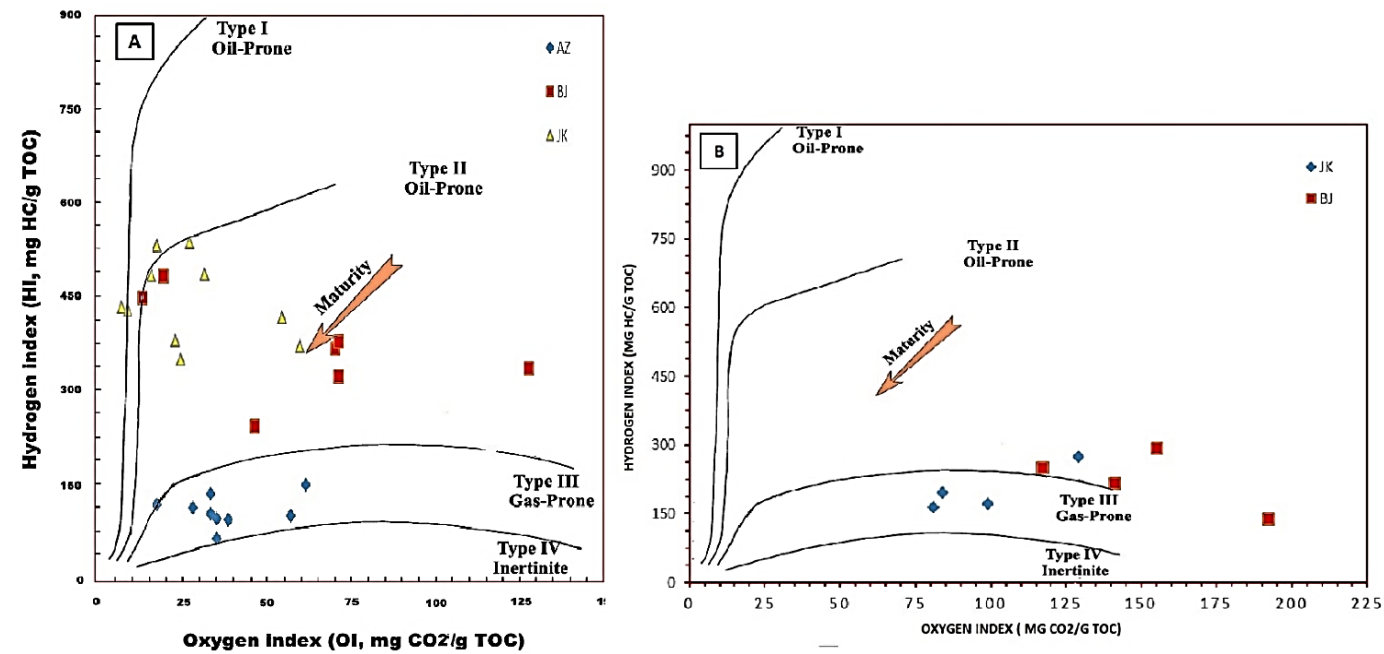

Fig.2. The HI/OI plot for various kerogen types. A) Sargelu Formation. B) Kurrachine Formation
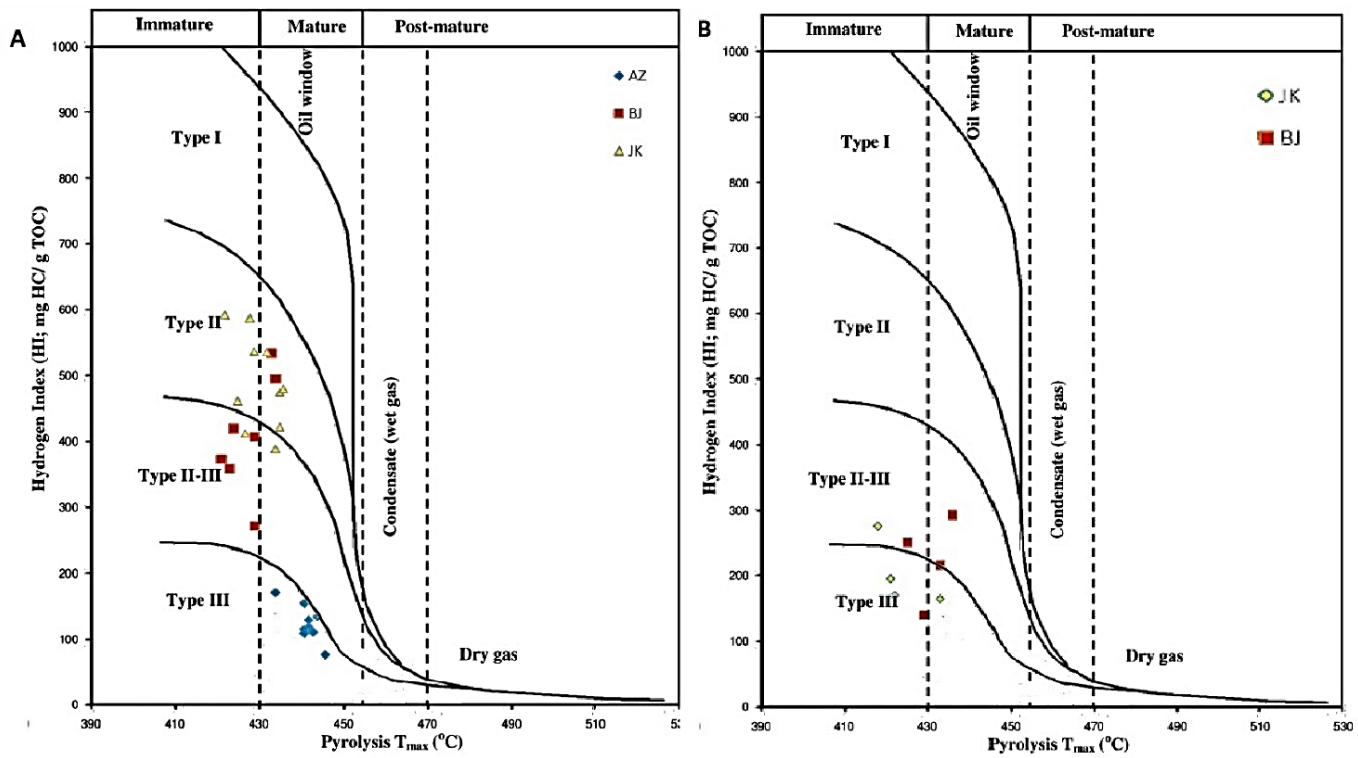

Fig. 3 Determination of kerogen type for source rock. A) Sargelu Formation. B) Kurrachine Formation

The methods and concepts were updated in 1980's and 1990's as additional methods were developed for the back-calculation of the original organic carbon, including the use of well logs to determine the TOC content. For example, the structural density of kerogen varies from $1.6 \mathrm{~g} / \mathrm{cc}$ for low-mature kerogen to up to $1.6 \mathrm{~g} / \mathrm{cc}$ for high-mature kerogen. 
Usually, Rock-Eval data is insufficient alone to characterize the types of kerogen present and the type of hydrocarbons it might generate (Dembicki, 2009). So, the Rock-Eval data needs other organic geochemical data to obtain accurate assessments of kerogen type. The plot of $\mathrm{Pr} / \mathrm{n}-\mathrm{C}_{17}$ against $\mathrm{Ph} / \mathrm{n}-\mathrm{C}_{18}$ (Fig.4) was used to evaluate the type of kerogen (Ghori, 2002) and it was shown that all samples fall within the type II kerogen. The pristane/n- $\mathrm{C}_{17}$ versus phytane / $\mathrm{n}-\mathrm{C}_{18}$ (Fig.5) also shows variations in source input, organic matter alterations, and sedimentary environments (Shanmugam, 1985). The extract samples are located in the reducing field, suggesting a more marine organic matter-rich source rock (Type II). Al-Atroshi et al. (2020) and Al-Dolaimy et al. (2021) both conclude that organic matter in Sargelu Formation derived from the marine depositional environment.

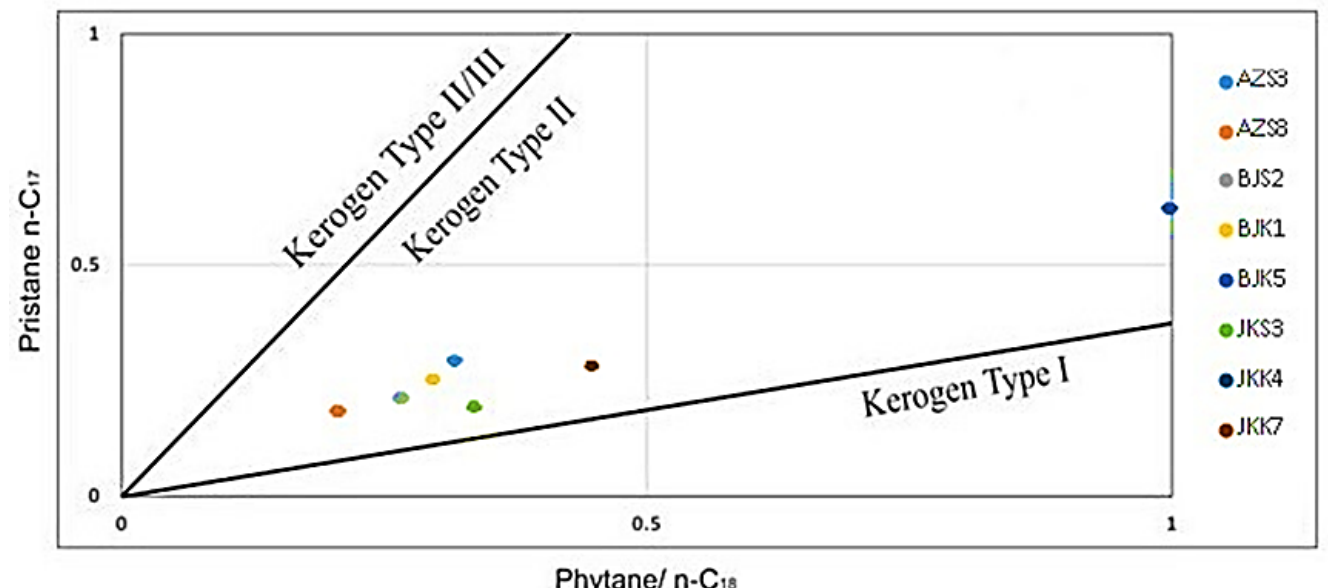

Fig. 4. Pristane/ $\mathrm{nC}_{17}$ versus Phytane/ $\mathrm{nC}_{18}$ plot of Sargelu and Kurrachine samples to identify the type of kerogen

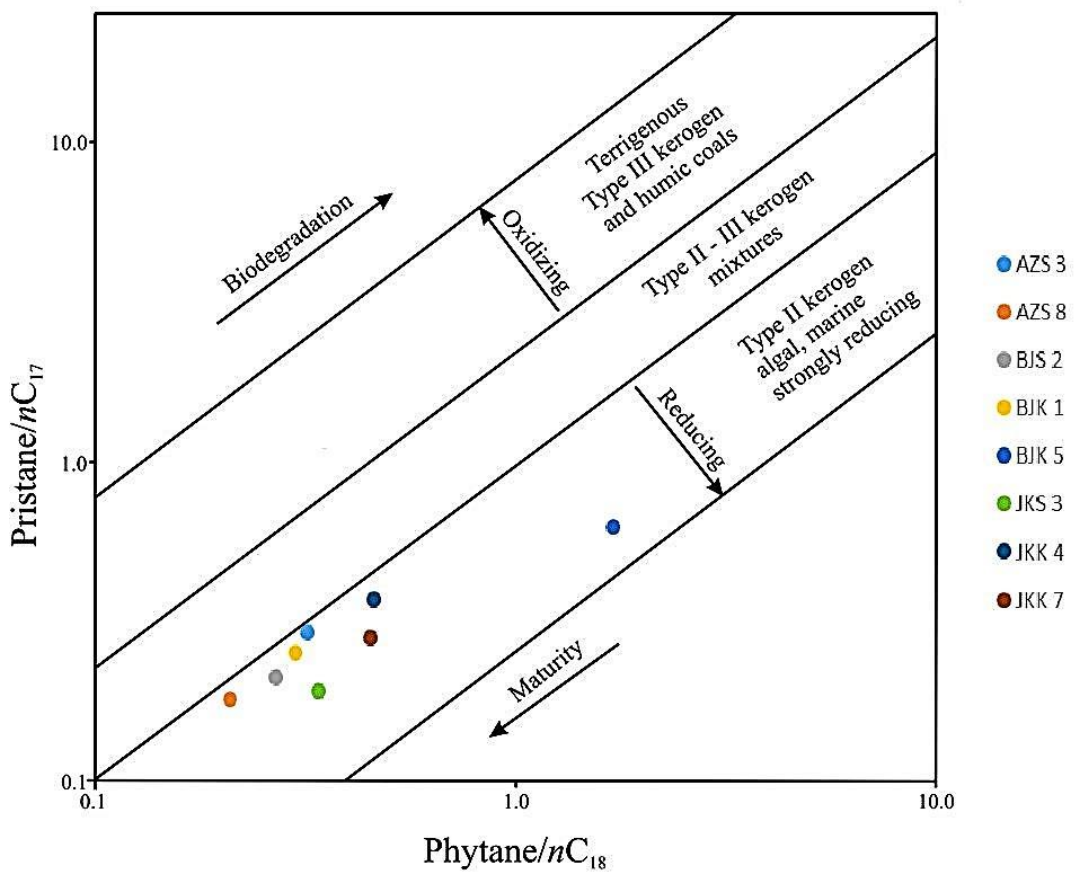

Fig. 5. Pristane $/ \mathrm{nC}_{17}$ versus Phytane/nC $\mathrm{n}_{18}$ plot of Sargelu and Kurrachine samples 


\subsection{Maturity}

Maturity refers to the amount of thermal change that organic matter undergoes as a result of heating (Peters and Cassa, 1994). Maturation of source rock happens in three stages: diagenesis, catagenesis, and metagenesis. The thermal maturity level of various types of organic matter can be evaluated from the Tmax range. Peters and Cassa (1994) mentioned that the beginning and end of the oil window are about $435-470{ }^{\circ} \mathrm{C}, 0.1-0.4$ for Tmax and PI, respectively. Tmax depends on the organic matter type and the matrix which surrounds the organic matter. The relationship between HI and Tmax is explained in Figs. 3A and 3B. It determines the types of organic matter in the rock. Likewise, it is used to determine maturity (Madukwe, 2014; El-Nady et al., 2015), and it has been observed that all samples of Ain Zalah well (Sargelu) are within the maturity range (oil window) while the samples of wells Baiji and Kand fall within the immature zone and graded to the mature zone. In the formation of Kurrachine in the Baiji well two samples fall within the maturity zone and two samples within the immature zone, while in $\mathrm{K}$ and Well, three samples within the immature zone and only one sample within the maturity zone.

Production index can be used to describe the level of organic matter maturity evaluation by plotting Tmax against PI for analyzed samples (Fig. 6A), it can be concluded that Ain Zalah source rock in the Sargelu Formation have PI values in the range 0.11-0.17 (Table 1), indicating that most of the source rocks of Ain Zalah within the main stage of hydrocarbon generation. While the Baiji and Jabel Kand samples are immature-early mature for hydrocarbon generation, also Baiji and Jabel Kand samples in Kurrchaine Formation are immature-early mature, (Fig. 6B).
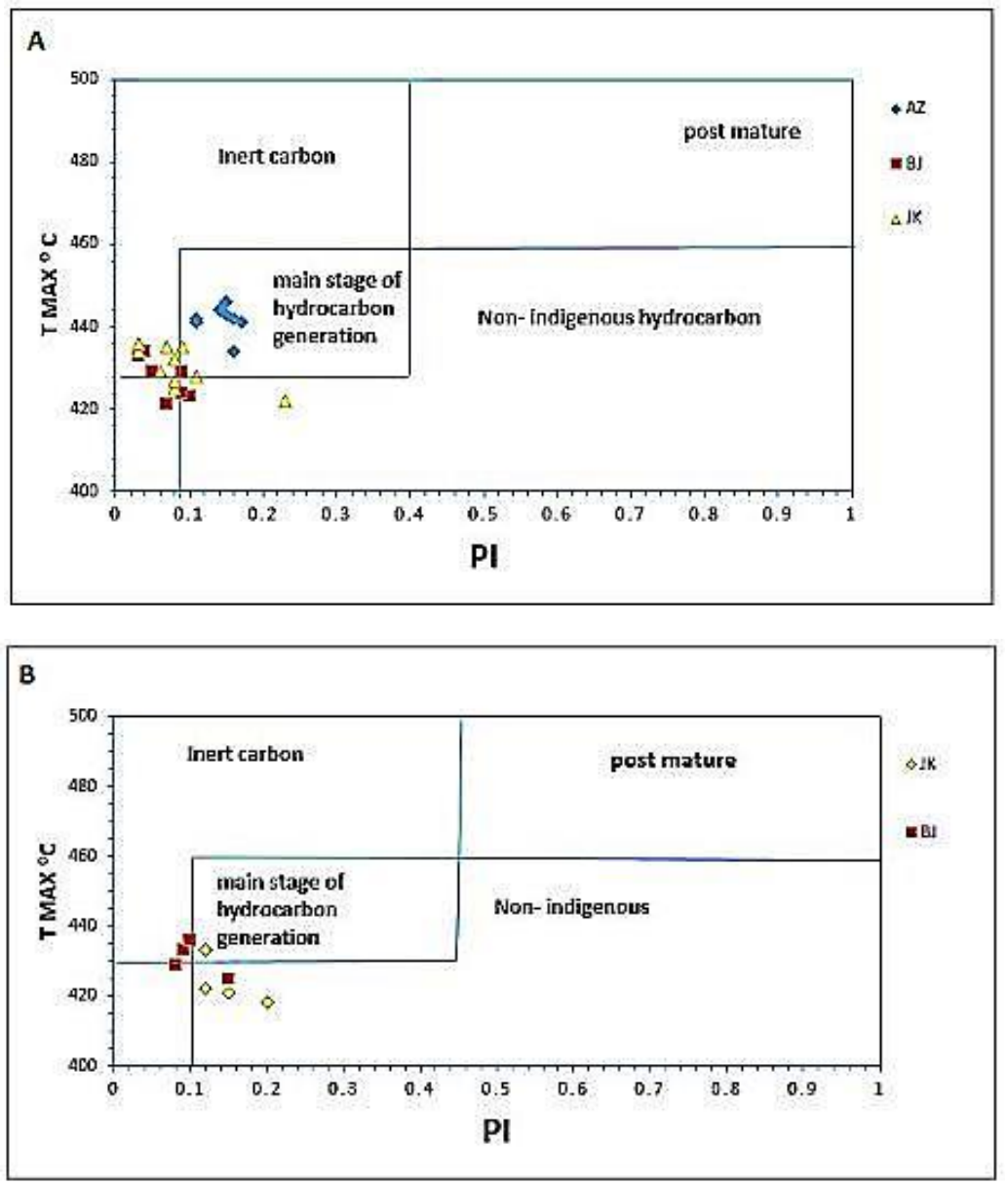

Fig. 6. Cross plot of pyrolysis PI versus Tmax, showing nature of the hydrocarbon product and maturation. A )Sargelu Formation. B)Kurrachine Formation 
Estimates of maturity in this study can be based on aromatic biomarkers. Aromatic steroid hydrocarbons are the main constituents of sediments and crude oils. They are derived from diagenetic processes of biogenic precursors or aromatization of natural products. Therefore, they have been used as indicators of maturity levels of oils and organic-rich sediments (Seifert and Moldowan, 1978; Mackenzie et al., 1981; 1982). Two types of aromatic steroids were identified using GC-MS analysis, mono- and triaromatic steroids characterized by their $\mathrm{m} / \mathrm{z} 253$ and 231 mass chromatogram fingerprints. Both showed alteration with increasing burial depth (Mackenzie et al., 1981). Triaromatic steroids are useful for estimating maturation because, with increased thermal maturity, long-chain triaromatic steroids $\left(\mathrm{C}_{27}, \mathrm{C}_{28} \mathrm{TAS}\right)$ degrades at a higher rate than the short-chain triaromatic steroids $\left(\mathrm{C}_{20}, \mathrm{C}_{21}\right.$ TAS $)$ (Beach et al., 1989). Since long-chain compounds are more vulnerable to thermal cracking than short-chains compounds, the proportion of short-chain components increases with maturity (Riolo et al., 1986). The analyzed samples showed $\left(\mathrm{C}_{20}+\mathrm{C}_{21}\right) / \sum$ TAS ratio from (0.08-0.55) (Table 3$)$, as this ratio was low in Kurrachine fformation samples, except JKK7, and an increase in this ratio was observed in the Sargelu Formation samples, to be higher than in sample AZS3(0.55).

The low concentration of monoaromatic was probably due to the maturity-driven aromatization to triaromatic (Mackenzie et al., 1981). Monoaromatic steroid hydrocarbon has been approved by many researchers like Seifert and Moldowan, (1978); Riolo et al. (1986) as potential geochemical parameters. However, it can be recognized that all studied samples contain significant amounts of $\mathrm{C}_{27}, \mathrm{C}_{28}$, and $\mathrm{C}_{29}$ monoaromatic except Ain Zalah samples (Fig. 7 and Table 3). There was no presence of monoaromatic $\left(\mathrm{C}_{27}, \mathrm{C}_{28}\right.$, and $\left.\mathrm{C}_{29}\right)$ in Ain Zalah samples (Sargelu Formation), this means that diagenetic processes are more advanced than in other wells, and the monoaromatic have started to crack. Monoaromatic steroids are primarily used to evaluate the correlation maturity and aromatization measured by comparing the ratio of TAS to MAS steroids, which is expressed by TAS/(MAS+TAS). It is generally accepted that during the maturation of sediments, the triaromatic are created by aromatization of monoaromatic as indicated in shale extracts (Mackenzie et al., 1981). When the thermal maturity level is increased, it is expected that the ratio of triaromatic/ monoaromatic steroids should increases gradually. The highest value of the TAS/(MAS+TAS) ratio was found in Ain Zalah samples (Sargelu Formation), (Table 3), and this result indicates the occurrence of an aromatization process with increasing thermal maturation at depths $2625,2720 \mathrm{~m}$.

\subsection{Ts/Tm Trisnorhopanes}

$\mathrm{Ts} / \mathrm{Tm}$ is commonly used as a saturated hydrocarbon maturity parameter. Ts exhibits greater thermal stability than its regular hopane rival, Tm. The reliability of this ratio, as a source maturity indicator is better when estimating oils from a common source of regular organic facies (Peters et al., 2005b). The value of this ratio alters from low in the immature range to high in the late oil generation stage (Moldowan et al., 1986). Kroon (2011) mentioned that the ratio of Ts/(Ts+Tm) between 0.55-0.88 indicates early to late oil generation. Source rock samples AZS3 (0.74), AZS8 (0.80), and JKK7 (0.63) (Table 3) indicating thermal maturities at the early oil generation stage.

\section{Discussion}

The source rock of Ain Zalah Well (Sargelu Formation) has Tmax values ranged from $434^{\circ} \mathrm{C}$ to $446{ }^{\circ} \mathrm{C}$, suggesting that the source rock in Ain Zalah is mature. The relationship between production index and Tmax data support this, indicating that the source rock in Ain Zalah is located in the main stage of hydrocarbon generation. Another method for determining the thermal maturity of source rock in Ain Zalah is aromatic hydrocarbon. The triaromatic steroids in oils are chiefly from (C20, C21) and (C26-C28) homolog. It is vastly accepted that triaromatic steroids probably formed by aromatization and the loss of a methyl group from monoaromatic (Peters et al., 2005b). Although the mechanism of 
this conversion is not clear, clay minerals may play a significant role as a catalyst (Rubinstein et al., 1975).

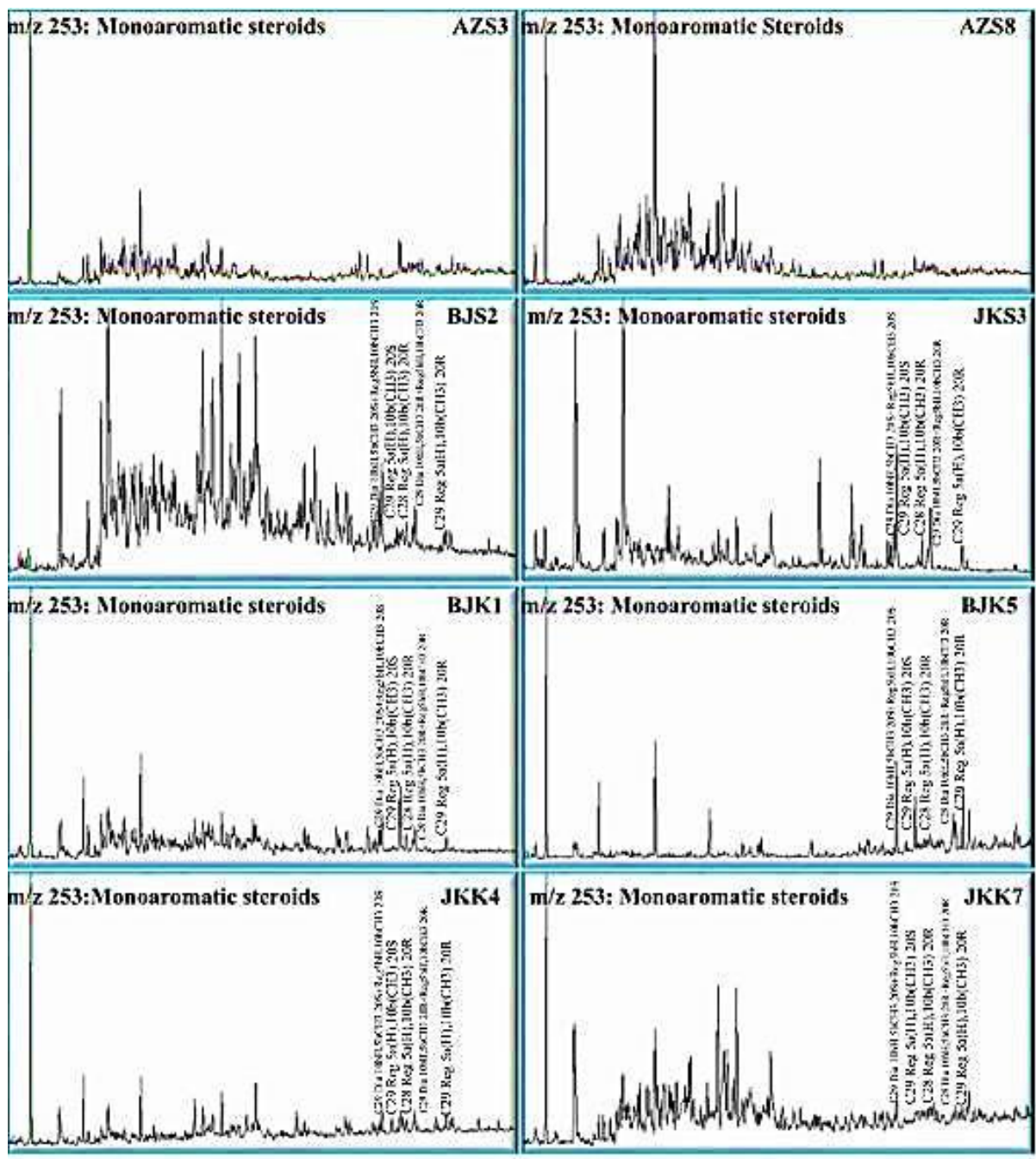

Fig. 7 GC/MS Chromatograms of monoaromatic (m/z 231) for analyzed samples

The transformations of $\mathrm{C}$ - ring monoaromatic to $\mathrm{ABC}$-ring triaromatic is related to the loss of both the methyl group $\left(-\mathrm{CH}_{3}\right)$ and the asymmetric center at $\mathrm{C}-5$. Organic matter type is type III, based on Rock-Eval pyrolysis. With an increase in maturity, TOC decrease because the transformation of $\mathrm{S}_{2}$ to oil. Present-day TOC refers to TOC total organic carbon that has been reduced by maturation (Jarvie, 2014). Therefore, in order to evaluate the indigenous petroleum potential, initial total organic matter needs to be determined. Initial TOC of a source rock provides a quantitative method for estimating the total volume of hydrocarbon that can be generated by the type of kerogen. For accurate assessments of the source rocks, gas chromatography has been relied on, which provides a direct indication of the type of kerogen. It was found that the organic matter in Ain Zalah Well is type II kerogen. Both Sargelu and Kurrachine formations in wells Baiji and Kand are gradient from immature to early mature based on Tmax and PI values.

\section{Conclusions}

The Sargelu Formation is rich in organic matter in the three wells. The source rock is classified as good in Ain Zalah to a very good in Baiji and excellent in Kand wells based on TOC wt.\% content, whereas the Kurrachine Formation has low the potentiality to generate hydrocarbons as classified as 
poor in Ain zalah and Kand to fair in Baiji wells. The principal kerogen type in Sargelu and Kurrachine formations is II based on the GC-analysis that produces oil and gas. In general, the samples in Sargelu Formation in Ain Zalaz Well have production index values ranging from 0.11-0.17 (average 0.14) and Tmax values ranging from $434{ }^{\circ} \mathrm{C}$ to $446{ }^{\circ} \mathrm{C}$ (average $442{ }^{\circ} \mathrm{C}$ ), suggesting that they are in early mature, while both Sargelu and Kurrachine formations are gradient from immature to early mature in wells Baiji and Kand based on Tmax and PI values. The degree of aromatization, measured by comparing the ratio of TAS to MAS steroids represented by TAS / (MAS + TAS), reached the highest value in the samples from Ain Zala Well.

\section{Acknowledgements}

The authors thank the North Oil Company in Kirkuk, Iraq for providing the cuttings samples. The authors are also very grateful to the Editor in Chief Prof. Dr. Salih M. Awadh, the Secretary of Journal Mr. Samir R. Hijab, and the Technical Editors for their great efforts and valuable comments.

\section{References}

Abdula, R. A., 2010. Petroleum Source Rock Analysis of the Jurassic Sargelu Formation, Northern Iraq, M.Sc. thesis, Colorado School of Mines, Golden, Colorado, United states, 106pp.

Abdula, R. A., 2015. Hydrocarbon potential of Sargelu Formation and oil-source correlation, Iraqi Kurdistan. Arabian Journal of Geosciences, 8(8), 5845-5868

Abdula R. A., Balaky, S. M., Nurmohamadi, M. S., and Piroui, M., 2015. Microfacies analysis and depositional environment of the Sargelu Formation (Middle Jurassic) from Kurdistan Region, northern Iraq, Donnish Journal of Geology and Mining Research, 1 (1), 1-26.

Abdula, R. A., 2016. Organic geochemical assessment of Jurassic potential source rock from Zab-1 Well, Iraqi Kurdistan, Iraqi Bulletin of Geology and Mining, 12 (3), 53-64.

Abdula, R. A., 2017. Petroleum system modeling of Jabal Kand Oil Field, Northern Iraq, ZANCO Journal of Pure and Applied Sciences, 29 (2), 88-95.

Abdula, R. A., Ali, M. A., Ahmed, M. M., and Hamad, H. R., 2017. Rock-Eval pyrolysis results from the Bijeel-1 Well, Kurdistan Region, Iraq, ZANCO Journal of Pure and Applied Sciences, 29 (3), 29-38.

Al-Ameri, T. K., Al-Dolaimy, Q. H., and Al-Khafaji, A. J., 2009. Palynofacies and hydrocarbon generation potential of the upper Triassic Kurrachine Formation lower part of the Baluti Formation, Mosul Block, Northwestern Iraq, Arabian Journal of Geosciences, 2 (3), 273-283.

Al-Ameri, T. K. and Zumberge, J., 2012. Middle and upper Jurassic hydrocarbon potential of the Zagros Fold Belt, North Iraq, Marine and Petroleum Geology, 36, 13-34.

Al-Ameri, T. K., Najaf, A. A., Al-Khafaji, A. S., Zumberge, J. and Pitman, J., 2013. Hydrocarbon potential of the Sargelu Formation, North Iraq, Arabian Journal of Geosciences, 7, 987-1000.

Al-Atroshi, S. J., Sherwani G. H. and Al-Naqshbandi S. F., 2020. Assessment the hydrocarbon potentiality of the Middle Jurassic Sargelu Formation, Northern Iraq, Iraqi Geological Journal, 53, 1-15.

Al-Badry, A. M. S., 2012. Stratigraphy and geochemistry of Jurassic formations in selected sections-north Iraq, Ph.D. thesis, University of Baghdad, Baghdad, Iraq, $162 \mathrm{pp}$.

Al-Dolaimy A.M., Al-Beyati F. M. and Al-Mallah A.Y., 2021. Distribution of steranes and triterpanes biomarkers indication of depositional environment and maturity of Sargelu and Kurrachine formations in different wells Northern Iraq, Iraqi Geological Journal, 54(1C), 87-100.

Aqrawi, A. A. M. and Badics, B., 2015. Geochemical characterization, volumetric assessment and shale-oil/gas potential of the middle Jurassic-Lower Cretaceous source rocks of NE Arabian Plate, Geo Arabia Journal, 20 (3), 99-140..

Awdal, A., Healy, D. and Alsop, G. I., 2016. Fracture patterns and petrophysical properties of carbonates undergoing regional folding: A case study from Kurdistan, N Iraq, Marine and Petroleum Geology, 71, 149-167.

Beach F., Peakman T. M., Abbott G. D., Sleeman R., Maxwell J. R., 1989. Laboratory thermal alteration of triaromatic steroid hydrocarbons, Organic Geochemistry, 14, 109-111. 
Bellen, R.C., Dunnington, H.V., Wetzel, R. and Morton, D.M., 1959. Lexique Stratigraphic International Paris, V. III, Asia, Fascicule 10a Iraq, 333 pp.

Buday, T., 1980. The Regional Geology of Iraq, Stratigraphy and Paleogeography (vol.1), Mosul, Iraq, Dar Al-Kutib Publishing House, University of Mosul, 445 pp.

Daly A. R. and Edman J. D., 1987. Loss of organic carbon from source rocks during thermal maturation, American Association of Petroleum Geologists Bulletin, 71, 546.

Dembicki Jr. H., 1993. Improved determination of source quality and kerogen type by combining Rock-Eval and pyrolysis-gas chromatography results, American Association of Petroleum Geologists 1993 Annual Convention Program, 2, 90.

Dembicki Jr. H., 2009. Three common source rock evaluation errors made by geologists during prospect or play appraisals, American Association of Petroleum Geologists Bulletin, 93, 341-356.

Edilbi, A. N. F., Kolo, K., Muhammed, N. R., Yasin, S. R., Mamaseni, W.J. and Akram, R., 2019. Source rock evaluation of shale intervals of the Kurrachine Formation, Kurdistan Region-Iraq: An organic geochemical and basin modeling approach, Egyptian Journal of Petroleum, 28, 315-321.

El-Nady M. M., Rammadan F. S., and Hammed M. M., Lotfy N. M. 2015. Evaluation of organic matters, hydrocarbon potential and thermal maturity of source rocks based on geochemical and statistical methods: case study of source rocks in Ras Gharib oil field central Gulf of Suez, Egypt, Egyptian Journal of petroleum, 24, 203-211.

Fatah, S. S. and Mohialdeen, I. M. J., 2016. Hydrocarbon generation potential and thermal maturity of middle Jurassic Sargelu Formation in Miran Field, Sulaimani Area, Kurdistan Region, NE Iraq, Journal of Zankoy Sulaimani, Special Issue, Geo Kurdistan II, 213-228.

Ghori K. A. R., 2002. High-quality oil-prone source rocks within carbonates of the Silurian Dirk Hartog Group, Gascoyne plat-from, Western Australia: Western Geological Survey Annual Review, 58-62.

Hakimi, M. H.., Najaf, A. A., Abdula, R. A., and Mohialdeen, I. M. J., 2017. Generation and expulsion history of oil-source rock (middle Jurassic Sargelu Formation) in the Kurdistan of north Iraq, Zagros Folded Belt: Implications from 1D basin modeling study, Journal of Petroleum Science and Engineering, DOI: 10.1016/j. petrol.2017.11.013.

Hunt, J. M., 1996. Petroleum Geochemistry and Geology, $2^{\text {nd }}$ ed. W.H. Freeman and Company, New York, 743 pp.

Hussein, F. S., El Kammar, M. M. and Sherwani, G. H., 2013. Organic geochemical assessment of Jurassic source rock from Duhok, North Iraq, Journal of American Science, 9 (1), 258-264.

Jarvie D. M., 2014. Components and processes affecting producibility and commerciality of shale resource system, Geologica Acta, Alago Special Publicatio, 12(4), 307-325.

Jassim, S. Z. and Al-Gailani, M., 2006. Hydrocarbon, chapter 18, In Jassim S. Z. and Goff J. C., (eds.), Geology of Iraq, first edition: Brno, Czech Republic, Prague and Moravian Museum, 232-250.

Jassim, S. Z. and Buday, T., 2006. Late-Toarcian - Early Tithonian (Mid-Late Jurassic) Megasequence AP7, chapter 10, In Jassim S. Z. and Goff, J. C., (eds.), Geology of Iraq, first edition: Brno, Czech Republic, Prague and Moravian Museum, 117-123.

Katz B. J., 1983. Limitations of Rock-Eval pyrolysis for typing organic matter, Organic Geochemistry, 4, 195-199.

Kroon, J., 2011. Biomarkers in the Upper Devonian Lower Huron Shale as Indicators of Biological Source of Organic Matter, Depositional Environment, and Thermal Maturity, M. Sc Thesis, Clemson University, 1166.

Leythaeuser, D., 2005. Origin migration and accumulation of petroleum, In: Amadei C. (ed.): Encyclopaedia of hydrocarbons, Istituto della Enciclopedia Italiana, Roma, 65-84 pp.

Mackenzie A. S., Hoffmann C. F., Maxwell J. R., 1981. Molecular parameters of maturation in the Toarcian shales, Paris Basin, France - III. Changes in aromatic steroid hydrocarbons, Geochimica et Cosmochimica Acta, 45, 1345-1355.

Mackenzie A. S., Patience R. L., Yon D. A., Maxwell J. R., 1982. The effect of maturation on the configurations of acyclic isoprenoid acids in sediments, Geochimica et Cosmochimica Acta, 46, 783-792.

Madukwe H. 2014. Organic matter quantity, quality and maturity studies of the Paleocene Ewekoro Formation, Southwestern Nigeria, Journal of Environment and Earth Science, 4, 118-130. 
Moldowan, J. M., Sundararaman, P., and Schoell, M., 1986. Sensitivity of biomarker properties to depositional environment and/or source input in the lower Toarcian of SW-Germany, Organic Geochemistry, 10, 915-926.

Peters, K. E., 1986. Guidelines for evaluating petroleum source rock using programmed pyrolysis, The American Association of Petroleum Geologists Bulletin, 70 (3), 318-329.

Peters, K. E. and Cassa, M. R., 1994. Applied source rock geochemistry, chapter 5. In Magoon L. B. and W. G. Dow, eds, The petroleum system-from source to trap: American Association of Petroleum Geologists Memoir, 60, 93-120.

Peters, K. E., Walters, C. C., and Moldowan, J. M., 2005a. The Biomarker Guide, Volume I, Biomarkers and Isotopes in the Environment and Human History, United Kingdom at the Cambridge University Press, $471 \mathrm{pp}$

Peters, K.E., Walters, C.C. and Moldowan, J.M., 2005b. The Biomarker Guide, Volume II, Biomarkers and Isotopes in petroleum Exploration and Earth History, United Kingdom at the Cambridge University Press, 475-1155.

Peters, K. E., Curry, D. J. and Kacewicz, M., 2012. An overview of basin and petroleum system modeling: Definitions and concepts, in Peters K. E., Curry D. J. and Kacewicz M., eds., Basin Modeling: New Horizons in Research and Applications: American Association of Petroleum Geologists Hedberg Series, 4, 1-16.

Riolo J., Hussler G., Albrecht P., Connan J., 1986. Distribution of aromatic steroids in geological samples: Their evaluation as geochemical parameters, Organic Geochemistry, 10, 981-990.

Rogers, M.A., 1979. Application of Organic Facies Concepts to Hydrocarbon Source Rock Evaluation, In: Proceedings of the $10^{\text {th }}$ World Petroleum Congress. World Petroleum Congress, Bucharest, Heyden, London, 2, 23-30.

Rubinstein I., Sieskind O., Albrecht P., 1975. Rearranged sterenes in a shale: Occurrence and Simulated Formation, Journal of the Chemical Society, Perkin Transactions I, 19, 1833-1836.

Seifert, W. K. and Moldowan, J. M., 1978. Applications of steranes, terpanes and monoaromatics to the maturation, migration and source of crude oils, Geochimica et Cosmochimica Acta, 42, 77-95.

Shanmugam, G., 1985. Significance of coniferous rain forests and related organic matter in generating commercial quantities of oil, Gippsland Basin, Australia, American Association of Petroleum Geologists Bulletin, 69, 1241-1254.

Tissot, B.P. and Welte, D.H., 1984. Petroleum Formation and Occurrence: A New Approach to Oil and Gas Exploration, $2^{\text {nd }}$ ed.: Springer-Verlag, Berlin, 699 pp.

Tyson, R.V., 1995. Sedimentary Organic Matter-Organic Facies and Palynofacies. Chapman and Hall, London, $615 \mathrm{pp}$.

Vandenbroucke, M., 2003. Kerogen: From types to models of chemical structure, Oil and Gas Science and Technology-Rev. IFP. 58, 243-269. 